tric power, Jakobshavn/llulissat, West Greenland. Ann. Glaciol. 13, 12-15.

Braithwaite, R. J., Olesen, O. B. \& Thomsen, H. H. 1992: Calculated variations of annual ice ablation at the margin of the Greenland ice sheet, West Greenland, 1961-90. J. Glaciol. 38(129), 266-272.

Clement, P. 1984: The drainage of a marginal ice-dammed lake at Nordbogletscher, Johan Dahl Land, South Greenland. Arctic Alp. Res. 16(2), 209-216.

GTO, 1975: Lokalisering af vandkraftressourcer på Grønlands vestkyst, $58 \mathrm{pp}$. Copenhagen: Grønlands Tekniske Organisation (unpublished report).

Nukissiorfiit, 1992: Vandkraftmuligheder og prioritering af vandkraftudbygningen i Grønland, $53 \mathrm{pp}$. Copenhagen: $\mathrm{Nu}$ kissiorfiit, Grønlands Energiforsyning (unpublished report).

Olesen, O. B. \& Braithwaite, R. J. 1989: Field stations for glacier-climate research, West Greenland. In Oerlemans, J. (ed.) Glacier fluctuations and climatic change, 207-218. Dordrecht: Kluwer Academic Publishers.

Thomsen, H. H. 1986: Photogrammetric and satellite mapping of the margin of the Inland Ice, West Greenland. Ann. Glaciol. 8, 164-167.
Thomsen, H. H. \& Braithwaite, R. J. 1987: Use of remotesensing data in modelling run-off from the Greenland ice sheet. Ann. Glaciol. 9, 215-217.

Thomsen, H. H. \& Olesen, O. B. 1991: Hydraulics and hydrology on the Inland Ice. Rapp. Gronlands geol. Unders. 152, 36-38.

Thomsen, H. H., Thorning, L. \& Olesen, O. B. 1989: Applied glacier research for planning hydro-electric power, Ilulissat/ Jakobshavn, West Greenland. Ann. Glaciol. 13, 257-261.

Weidick, A. 1990: Investigating Greenland's glaciers. Rapp. Grønlands geol. Unders. 148, 46-51.

Weidick, A. 1991: Present-day expansion of the southern part of the Inland Ice. Rapp. Grønlands geol. Unders. 152, 73-79.

Weidick, A. \& Thomsen, H. H. 1986: A decade of glacier investigations for utilisation of Greenland hydropower. Rapp. Grønlands geol. Unders. 128, 157-169.

H. H. T., R. J. B., A. W. \& O. B. O., Geological Survey of Greenland, Copenhagen.

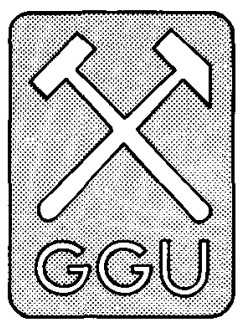

\title{
Measurements of firn density in the lower accumulation area of the Greenland ice sheet: EPOCH 1992
}

\author{
Roger J. Braithwaite and Martin Laternser
}

Groups from several countries are studying Greenland glaciers in connection with the 'greenhouse effect' (Braithwaite et al., 1992a). In particular, GGU is the Danish partner in a 10-nation two-year project (March 1991 to February 1993) on causes and effects of sea level changes which is funded by the European Community through the European Programme on Climatology and Natural Hazards (EPOCH). As its contribution to EP$\mathrm{OCH}, \mathrm{GGU}$ is studying the effects of meltwater refreezing in the lower accumulation area of the Greenland ice sheet which may reduce, or at least delay, the expected sea level rise under warmer climate.

Work done under EPOCH in 1991 was described by Braithwaite et al. (1992b) while the present note describes the most important results of the 1992 field work.

\section{Background}

The field area is above Paakitsoq (formerly spelt Pâkitsoq), about $80-120 \mathrm{~km}$ east of Ilulissat/Jakobshavn (Fig. 1), where GGU has measured mass-balance in the ablation area since 1982 (Thomsen et al., 1989). A line of accumulation stakes was established in 1990 and 1991 from the upper part of the ablation area to well within the accumulation area (see sketch map in Braithwaite $e t$ $a l ., 1992 b)$. Three-dimensional stake positions were measured at various times with a hand-held Global Positioning System (GPS), and elevations of stakes and surface features are shown in Table 1 with an estimated accuracy of $\pm 35 \mathrm{~m}$.

Observations in 1991 strongly suggested that firn densification, and especially the change of firn to ice, is a 


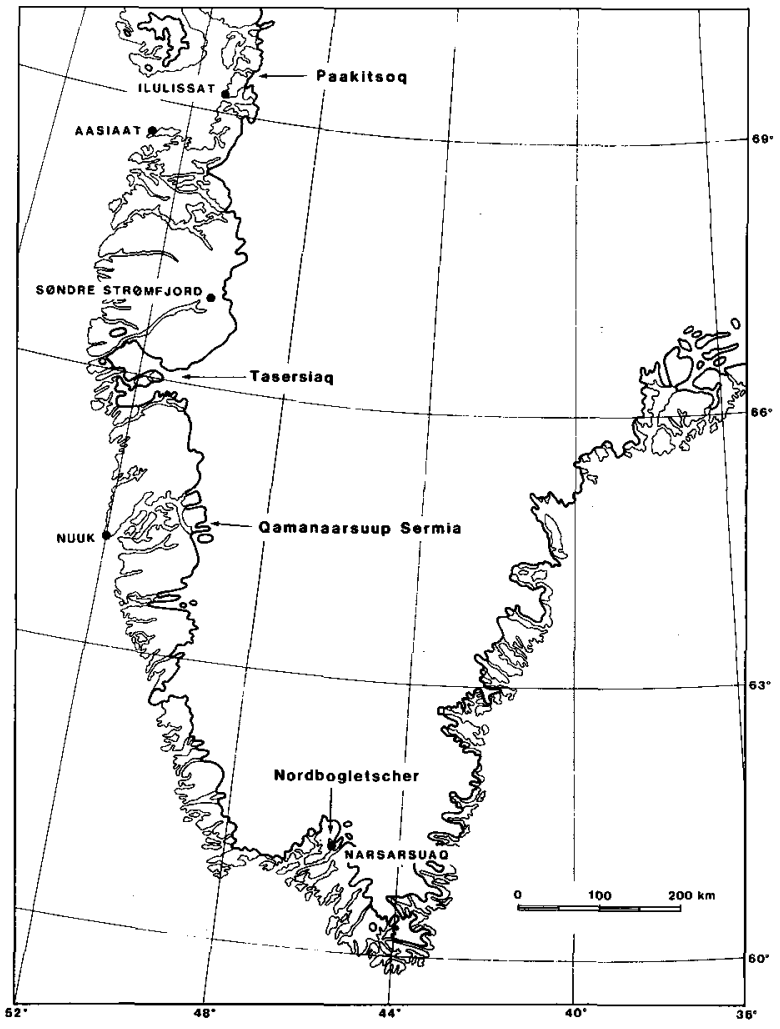

Fig. 1. Location map showing GGU's glacier-climate stations on the Greenland ice sheet, West Greenland, including Paakitsoq, the location of studies described in this report.

key process determining the extent and location of the refreezing zone, and the stretch between stakes 151 and 165 was therefore chosen for detailed study in the 1992 EPOCH field work.

\section{Logistics}

Glaciological work in the lower accumulation zone involves severe problems of logistics and communications. This is probably why there are few data from this zone and, in particular, why GGU has never been able to make regular mass-balance measurements here.

Measurements have been made in the ablation area with great success over the last 10 years by flying each day by helicopter from Ilulissat (Thomsen et al., 1989). However, this so-called 'flying squad' approach is inappropriate for measurements in the lower accumulation area because of the greater distances and elevations involved, the extra weight of equipment needed and the time-consuming nature of the measurements, e.g. a detailed density profile at a single site down to 10 metres depth needs a very long day's work. Further problems are the difficulties of getting weather information from the area, and the hazard of flying over snow-covered surfaces when there is overcast sky. These problems were solved in 1992 by a combination of helicopter transport to and from the field area and man-hauling within the area.

Field work was carried out between 7 May and 17 May. Temperatures were well below freezing throughout the whole field period and there was no melting. The main hazard was nearly continuous high wind and snow drift combined with low air temperatures (down to $-32^{\circ} \mathrm{C}$ ). However, it was possible to work on every day and to travel between stakes by ski, using compass and GPS for navigation, even when ground visibility was too bad for a helicopter. The relative discomfort of the field work was therefore more than compensated by its greater effectiveness. The authors were flown into the area from Ilulissat and camped for a few days each at stakes 163 and at 157. Movement between stakes 151 to 165 was on ski and equipment was pulled on small sledges as crevasses were thought to be absent in this stretch. However, the stakes 122 to 141 , in areas with extensive crevasses, were only visited by helicopter.

Table 1. Elevations of stakes and surface features in the study area, Paakitsoq, West Greenland. Surface features as seen in 1990

Stake

Surface features

Elevation m a.s.l.

122

\begin{tabular}{lr} 
Glacier ice & 1180 \\
Crevasse field & \\
Equilibrium line & c. 1200 \\
Superimposed ice & 1260 \\
Crevasse field & \\
Large river & \\
Superimposed ice? & 1260 \\
Crevasse field & \\
Superimposed ice? & 1340 \\
Slush field & \\
Superimposed ice & 1350 \\
Crevasse field & \\
Firn limit & \\
Runoff limit & \\
Icy firn & \\
Icy firn & 1440 \\
Firn & 1510 \\
Firn & 1530 \\
Firn & 1620 \\
Wet-snow line & 1620 \\
\hline
\end{tabular}

1180

260

1800 


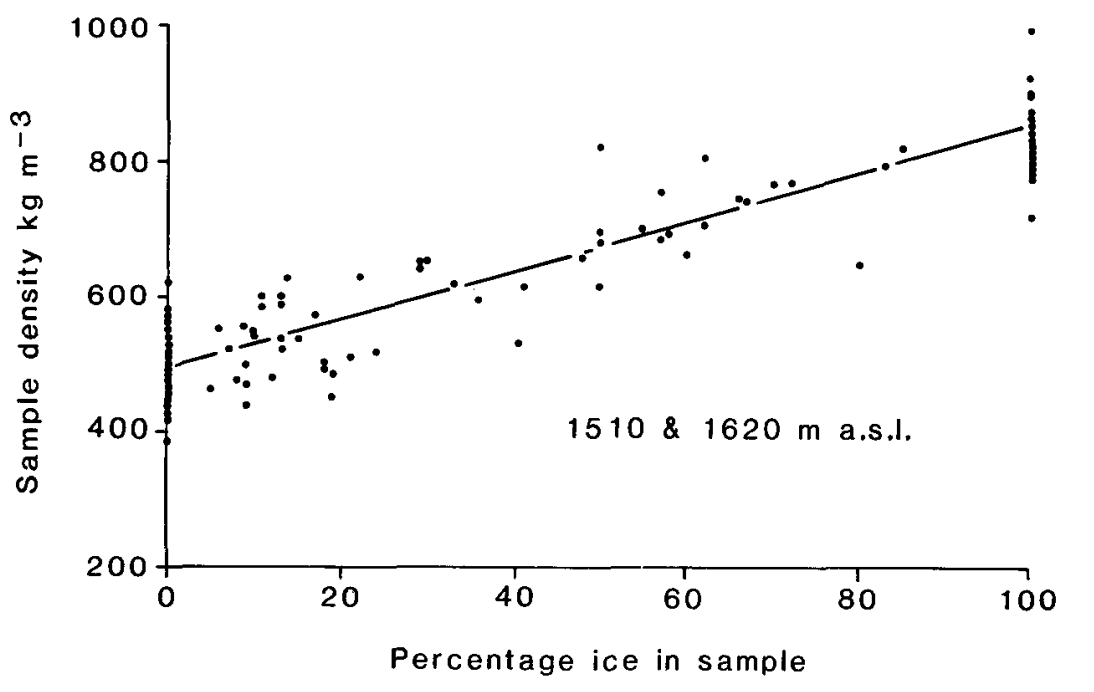

Fig. 2. Sample density versus percentage of ice for two 10 metre cores, lower accumulation area, Paakitsoq, Greenland ice sheet.

\section{Data collection}

Snow pits were dug in the 1991/92 winter snow at the five stakes 151 to 165 , and snow samples were taken from the walls of the pit. Firn samples from below the snow pits were taken by a SIPRE corer; to depths of almost 10 metres at stakes 157 and 163, and to depths of 5 metres at the other three sites.

Snow and firn densities were determined by weighing samples and measuring their volumes. Thicknesses of any ice layers were also measured. Depths of samples were estimated by measuring the depth of the SIPRE bore-hole after each sample extraction.

In addition to the density measurements, firn temperatures were measured to 10 metres depth at a number of stakes using thermistor strings emplaced in 1991 by steam drill.

\section{Results}

Densities were obtained for 221 firn șamples from below the 1991 summer surface as well as for 15 samples from the 1991/92 winter snow. Firn samples were classified into three groups according to ice content: 'firn' samples with no visible sign of ice, 'ice' samples which appear to consist solely of ice, and 'firn/ice' samples with ice layers within the firn. Despite some subjectivity in determining ice content, density is clearly controlled by the amount of ice in the sample (Fig. 2), in contrast to higher elevations where density is controlled by compressive deformation (Benson, 1962). As the ice can only be created by refreezing of meltwater from the surface (and any rain), firn density variations reflect the amount of surface melting and subsequent refreezing within the top 2-4 metres of the firn pack.

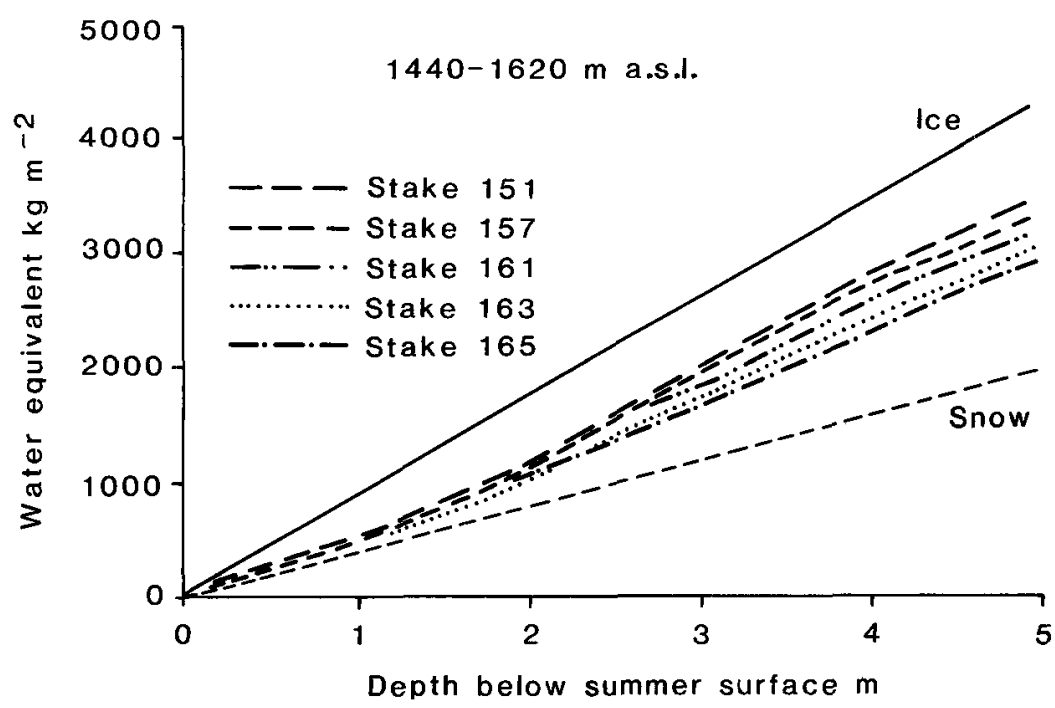

Fig. 3. Cumulative water equivalent versus depth for five 5metre cores, lower accumulation area, Paakitsoq, Greenland ice sheet. 
Fig. 4. Cumulative water equivalent versus depth for two 10metre cores, lower accumulation area, Paakitsoq, Greenland ice sheet.

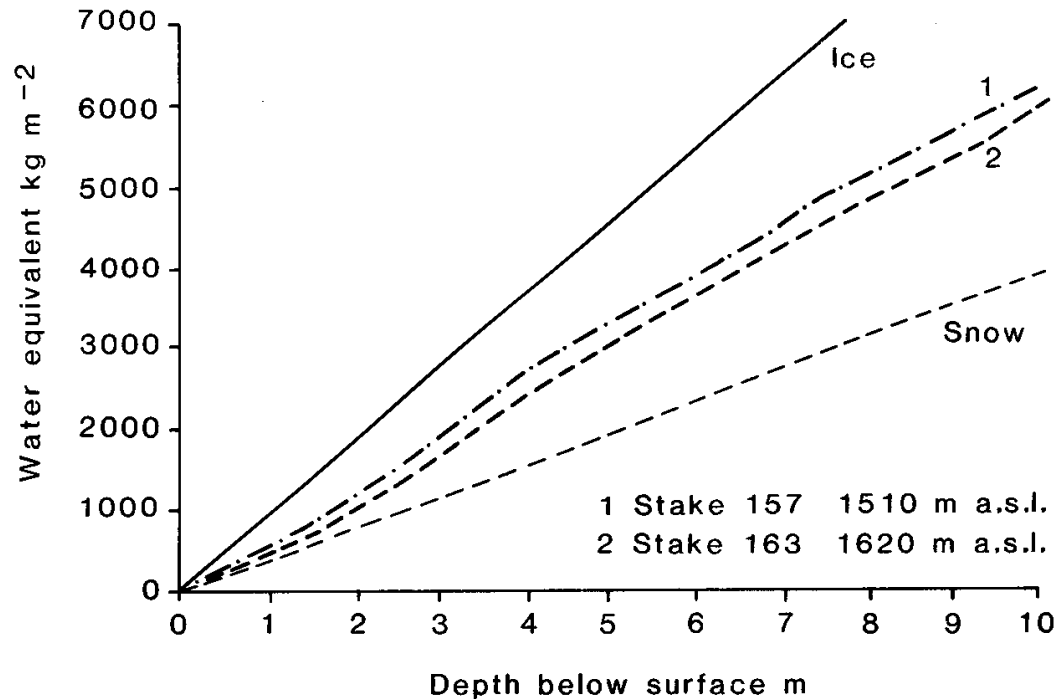

Firn densities vary greatly from sample to sample, but a general impression of average conditions at any site can be obtained by plotting water equivalent versus depth, otherwise known as load-depth curves (Benson, 1962). The gradients of such plots represent densities. Load-depth curves for the five stakes (Fig. 3) show a clear relation between average firn density and rising elevation above the runoff limit. The lines for 'ice' and 'snow' (with densities of 375 and $890 \mathrm{~kg} \mathrm{~m}^{-3}$ respectively) are guide-lines, as all load-depth curves must lie between these limits. Although stake 151 is only about $40 \mathrm{~m}$ higher than the runoff limit at about $1400 \mathrm{~m}$, its load-depth curve lies far below that for 'ice'. This suggests a very rapid change in density immediately above the runoff limit.

Load-depth curves for stakes 157 and 163, where firn samples were collected to a greater depth of 10 metres, show a surprising decrease of density below about 4 metres (Fig. 4). This confirms observations in 1991 by T. Pfeffer (Braithwaite et al., 1992b) and may show that there was less melting a few years ago, e.g. in the late 1970s and early 1980s, when this firn was passing through the surface layer with refreezing of meltwater.

\section{Outlook}

Analysis of field data is now complete and firn density is being modelled in terms of snow melting at the surface which, in turn, is modelled from climatological data using the GGU degree-day model with modifications inspired by Pfeffer et al. (1991). In particular, the latter identify the ratio of annual melting to annual accumulation as an important parameter describing melting/ refreezing. The purpose of the modelling is to calculate the runoff which may occur in the future from the present refreezing zone, and the results will be reported to the European Community in fulfilment of GGU's obligations to the EPOCH programme.

Acknowledgements. The work was supported by the European Community under the European Programme on Climatology and Natural Hazards (EPOCH) through contract EPOCCT90-0015 which is coordinated by Professor D. Smith (Coventry University, U.K.). Helicopter support from Ilulissat was coordinated by H. H. Thomsen (GGU).

\section{References}

Benson, C. S. 1962: Stratigraphic studies in the snow and firn of the Greenland ice sheet. Res. Rep. Snow Ice Permafrost Res. Establ. 70, 89 pp.

Braithwaite, R. J., Reeh, N. \& Weidick, A. 1992a: Greenland glaciers and the 'greenhouse effect', status 1991. Rapp. Grønlands geol. Unders. 155, 9-13.

Braithwaite, R. J., Pfeffer, W. T., Blatter, H. \& Humphrey, N. F. 1992b: Meltwater refreezing in the accumulation area of the Greenland ice sheet: Pâkitsoq, summer 1991. Rapp. Grønlands geol. Unders. 155, 13-17.

Pfeffer, W. T., Illangasekare, T. H. \& Meier, M. F. 1991: Retention of Greenland runoff by refreezing: implications for projected future sea level change. J. geophys. Res. 96(C12), $22117-22124$.

Thomsen, H. H., Olesen, O. B., Braithwaite, R. J. \& Weidick, A. 1989: Greenland ice-margin programme, a pilot study at Pâkitsoq, north-east of Jakobshavn, central West Greenland. Rapp. Grønlands geol. Unders. 145, 50-53.

R. J. B., Geological Survey of Greenland, Copenhagen. M. L., Laboratory of Hydraulics, Hydrology and Glaciology, Swiss Federal Institute of Technology, ETH-Zentrum, CH-8092 Zürich, Switzerland. 